\title{
Credit Cards: Use and Consumer Attitudes, 1970-2000
}

Thomas A. Durkin, of the Board's Division of Research and Statistics, prepared this article. Nicole Price provided research assistance.

A notable change in consumer financial services over the past few decades has been the growth of the use of credit cards, both for payments and as sources of revolving credit. From modest origins in the 1950s as a convenient way for the relatively well-to-do to settle restaurant and department store purchases without carrying cash, credit cards have become a ubiquitous financial product held by households in all economic strata.

In modern commerce, credit cards (along with debit cards) serve as a payment device in lieu of cash or checks for millions of routine purchases as well as for many transactions that would otherwise be inconvenient, or perhaps impossible (for example, making retail purchases by telephone or over the Internet). Credit cards have also become the primary source of unsecured open-end revolving credit, and they have largely replaced the installment-purchase plans that were important to the sales volume at many retail stores in earlier decades.

Along with most major societal changes come questions about whether the trend is beneficial or detrimental (or somewhere in between), and the rise of plastic cards for payments and open-end credit is no exception. Credit cards certainly are widely used and accepted by the public. But they have also raised concerns in two areas: (1) whether consumers fully understand the costs and implications of using credit cards (the consumer information-consumer understanding concern) and (2) whether credit cards have encouraged widespread overindebtedness, particularly among those least able to pay (the indebtedness-financial distress concern). The two issues are related, because one result of lack of understanding may be overindebtedness. Both issues remain prominent in public discourse, as debt and personal bankruptcy levels have increased over the decades and media reports of confused consumers have multiplied.

Although one can usually find anecdotes to illustrate a point-consumers who are unaware of the costs of credit cards, for instance, or consumers who overspend because of the wide availability of creditsuch examples can never lead to a definitive understanding of issues having broad social or economic impact. Statistically representative surveys can contribute to a more complete understanding of consumers' experiences. Taken together, such surveys can serve as a status report on the use of credit cards some fifty years after their introduction. This article brings to the discussion some survey evidence on the use of credit cards in the United States. It begins with an examination of long-term trends in consumer indebtedness, with attention to the growth of cardbased credit. It then moves to an exploration of the consumer information-consumer understanding issue, with emphasis on consumers' attitudes toward credit cards and their knowledge of costs.

\section{CREDIT CARDS AND INDEBTEDNESS}

The Federal Reserve Board collects data on amounts of consumer credit outstanding, including amounts of revolving consumer credit, most of which is generated by credit cards. ${ }^{1}$ Total (nonmortgage) consumer credit outstanding increased from $\$ 119$ billion at year-end 1968 to $\$ 1,456$ billion in June 2000 (in current dollars, not seasonally adjusted), while the revolving component grew from $\$ 2$ billion to about $\$ 626$ billion over the same period. Because population, income, employment, prices, and nearly every other economic indicator also rose over the period, the growth of consumer credit is often put in perspective by comparing it with the growth of consumers' income.

Total (nonmortgage) consumer credit outstanding (revolving and nonrevolving forms combined) has

1. Consumer credit covers most short- and intermediate-term credit extended to individuals. It includes revolving credit (credit card credit and balances outstanding on unsecured revolving lines of credit) and nonrevolving credit (such as secured and unsecured credit for automobiles, mobile homes, trailers, durable goods, vacations, and other purposes). Consumer credit excludes loans secured by real estate (such as mortgage loans, home equity loans, and home equity lines of credit). 
1. Consumer credit outstanding as a proportion of disposable personal income, 1956-99

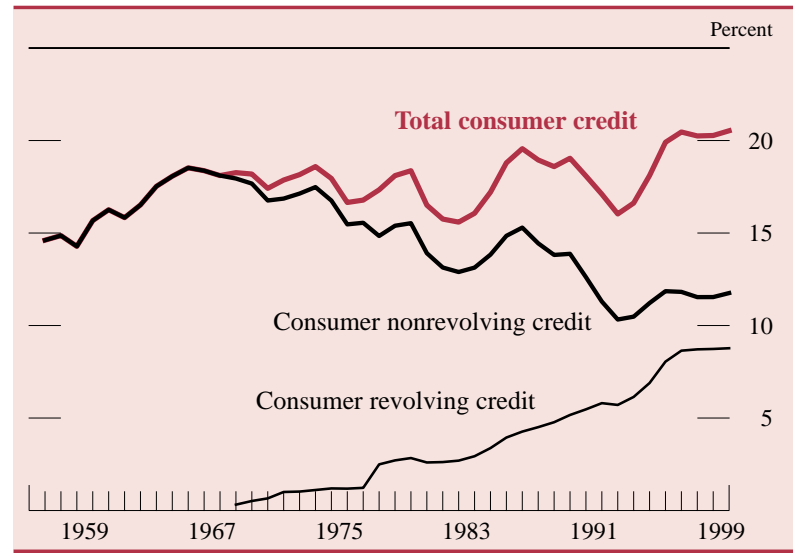

Source. Federal Reserve Board and Bureau of Economic Analysis.

grown at approximately the same pace as disposable personal income over the past generation, although with noticeably more cyclicality. Since the mid1960s, total consumer credit outstanding relative to this measure of income has fluctuated in a relatively narrow range of about 16 percent to 17 percent during or following recession periods to about 18 percent to 21 percent near business-cycle highpoints (chart 1).

The revolving component of consumer credit has increased relative to income over the most recent three decades, and the nonrevolving component has decreased relative to income. Thus, the revolving component's share has been growing relative to the nonrevolving component's share, reflecting consumer preference and technological change; many consumers seem to like the convenience associated with prearranged lines of credit, and technological developments have made it much easier for creditors to offer this data-intensive product. A substantial portion of the new revolving credit probably has merely replaced credit generated by the installment-purchase plans that were common at appliance, furniture, and other durable goods stores in the past. And some of the new credit is in the form of "convenience credit" on credit cards-amounts that will be paid in full upon receipt of the monthly statement. (Installmentpurchase plans have no equivalent "convenience" component.)

\section{Card Holding among Families}

Dollar amounts of credit card credit outstanding can be estimated from information provided by creditors, but only surveys of consumers can provide informa- tion about the users and uses of credit cards. For this reason, each Survey of Consumer Finances since 1970 has included questions on the holding and use of credit cards (the 1967 and 1968 surveys also included a few questions about credit cards). ${ }^{2}$

These surveys show that in 1998 almost threefourths of American families had one or more credit cards, up from about one-half of a smaller population in 1970 (table 1). Among credit cards, the generalpurpose cards that have a revolving feature, referred to in this article as "bank-type" credit cards, show the most notable increase over the period. ${ }^{3}$ In the early 1970s, limited-use cards issued by retail firms, usable only in the firm's stores, were the most commonly held type of credit card; bank-type cards were much less common. By 1995, however, the holding of bank-type cards was more common than the holding of retail store cards.

The holding of bank-type credit cards has continued to grow in recent years, whereas the holding of retail store cards peaked about a decade ago and has fallen off since then. In fact, bank-type cards issued under the Visa and MasterCard brands are so widely held and used today that it is difficult to imagine that they were not especially common only three decades ago. Known at that time as BankAmericard and Master Charge, respectively, and issued only by commercial banking organizations, they were a new product in the mid-1960s and by 1970 together had reached only about one-sixth of families; the other major bank-type cards widely available today, Discover and Optima, were not even on the drawing boards at that time. By 1998, bank-type cards (including Discover and Optima) were in the hands of about two-thirds of families. In three decades, the general-purpose card with a revolving feature has become the most widely held credit device.

Consumers use credit cards for two main purposes: as a substitute for cash and checks when making purchases and as a source of revolving credit. In 1970 , just over one-fifth of all families owed a balance on a credit card after making their most recent card payment (table 1). By 1998, the fraction was just over two-fifths. Most of the increase was due to the

2. The Survey of Consumer Finances series is sponsored by the Federal Reserve Board, sometimes jointly with other agencies. The 1977 survey in this series was titled the 1977 Consumer Credit Survey but is referred to in this article as the 1977 Survey of Consumer Finances because it is part of the same series. For a general description of results from recent surveys, see Arthur B. Kennickell, Martha Starr-McCluer, and Brian J. Surette, "Recent Changes in U.S. Family Finances: Results from the 1998 Survey of Consumer Finances," Federal Reserve Bulletin, vol. 86 (January 2000), pp. 1-29.

3. "Travel and entertainment" cards such as American Express and Diners Club are not included here as "bank-type" cards because they do not offer a revolving feature. 
1. Prevalence of credit cards among U.S. families, selected years, 1970-98 Percent

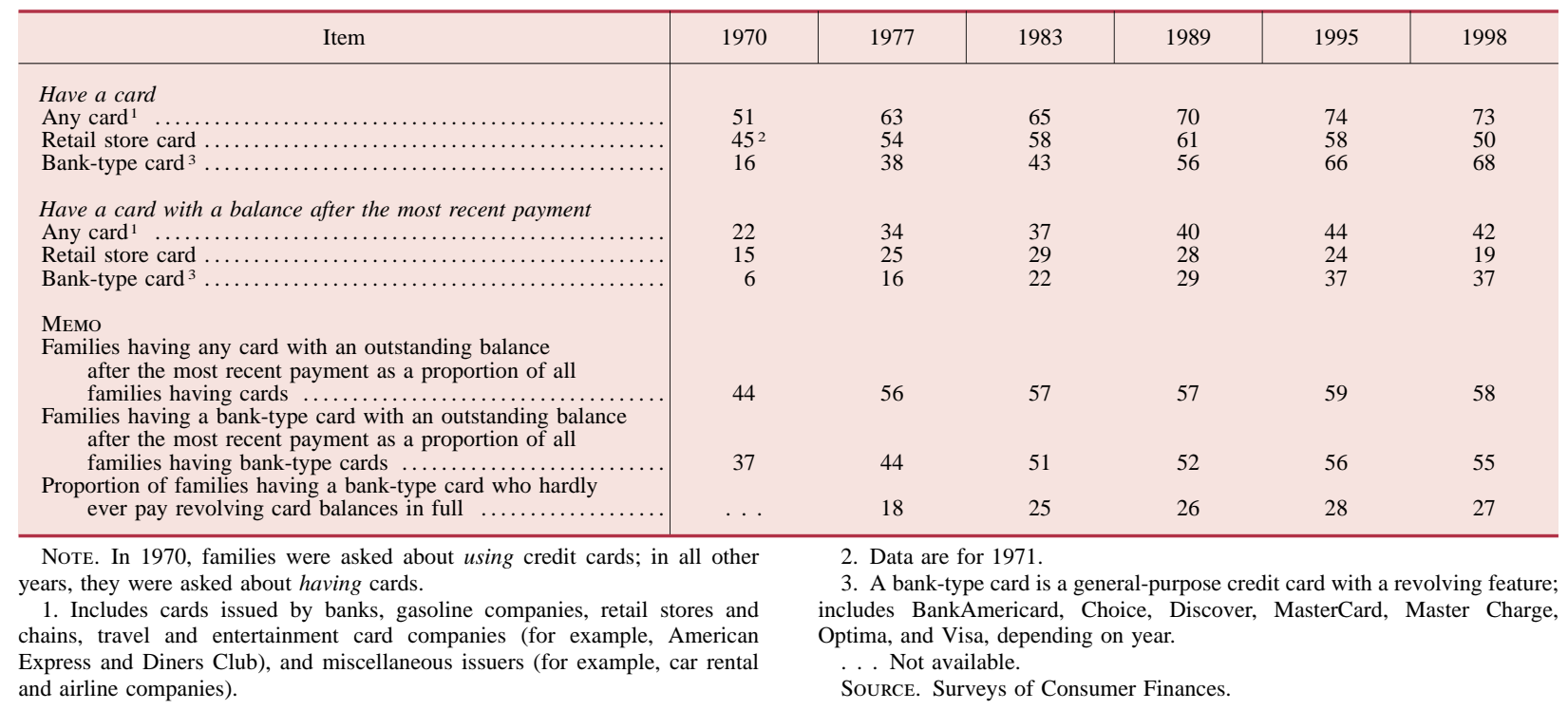

growing popularity of bank-type cards as devices for generating revolving credit. In 1970, only 6 percent of families had a bank-type card with an outstanding balance after their most recent payment. The proportion rose steadily until 1995 and then leveled off at 37 percent. In contrast, the proportion of families reporting an outstanding balance on a retail store card peaked in 1983 at 29 percent, and in 1998, at 19 percent, it was only a bit higher than the 15 percent recorded in 1970. Of those families that had banktype cards, 37 percent had revolved a balance in the month before the 1970 survey, compared with 55 percent in the month before the 1998 survey. In 1977, 18 percent of holders of bank-type cards reported that they hardly ever paid their revolving accounts in full, a proportion that rose to 25 percent in 1983 and has remained at about that level since then.

\section{Distribution of Bank-Type Credit Cards}

Data from the Surveys of Consumer Finances indicate that the holding of general-purpose credit cards with a revolving feature has become more widespread among households at all income levels. For families in the lowest income group, 2 percent had a bank-type credit card in 1970, compared with 28 percent in 1998 (table 2). For those in the highest income group, the holding of bank-type cards almost tripled between 1970 and 1995-from 33 percent to 95 percent.

For each income group, the percentage of cardholders carrying a balance on bank-type cards also increased over the three decades, as did the mean and median revolving credit balances (in constant dollars). Despite some shifts within the period, the shares of total revolving balances on these cards accounted for by each income group has not changed dramatically over the decades, perhaps contrary to popular impressions. For example, despite a sharp increase in card holding by the lowest income group, the group's share of total revolving debt on bank-type cards rose only to 5 percent in 1998, up from 2 percent in 1970 but still not a large proportion of the total. The highest income group accounted for 30 percent of revolving debt on bank-type cards in 1970, a share that over the three decades fell off only a bit, to 29 percent in 1998.

The expanded availability of card-based credit, especially to lower-income consumers, has raised concerns that issuers have taken on more credit risk and that instances of financial distress may increase sharply at some point. Data on the proportion of dollars of revolving credit delinquent thirty days or more, available from Call Reports submitted by commercial banks since 1991, indicate an upward trend from 1994 to 1996 and a leveling after that (chart 2). This pattern is similar to that for delinquencies on closed-end (nonrevolving) consumer credit extended by banks, much of which is secured credit associated with the purchase of automobiles. Data on the proportion of consumers (rather than dollars) delinquent, assembled by the Credit Research Center (Georgetown University) from a random sample of consumer credit reports maintained by a national credit reporting agency, show that at year-end 1999, 3.4 percent 
2. Prevalence of bank-type credit cards and outstanding balance amounts, by family income quintiles, selected years, 1970-98

Percent except as noted

\begin{tabular}{|c|c|c|c|c|c|c|}
\hline Income quintile & 1970 & 1977 & 1983 & 1989 & 1995 & 1998 \\
\hline \multicolumn{7}{|l|}{ Lowest } \\
\hline Have a card & 2 & 11 & 11 & 17 & 28 & 28 \\
\hline Carrying a balance & 27 & 40 & 40 & 43 & 57 & 59 \\
\hline Mean balance (dollars) & 896 & 731 & 1,147 & 784 & 2,386 & 2,240 \\
\hline Median balance (dollars) & 336 & 538 & 818 & 592 & 995 & 700 \\
\hline Share of total revolving balance & 2 & 4 & 4 & 2 & 6 & 5 \\
\hline \multicolumn{7}{|l|}{ Second lowest } \\
\hline Have a card .. & 9 & 22 & 27 & 36 & 54 & 58 \\
\hline Carrying a balance & 39 & 42 & 49 & 46 & 57 & 58 \\
\hline Mean balance (dollars) & 659 & 1,055 & 906 & 1,712 & 2,622 & 3,028 \\
\hline Median balance (dollars) & 504 & 565 & 655 & 1,315 & 1,605 & 1,400 \\
\hline Share of total revolving balance & 9 & 13 & 8 & 8 & 14 & 13 \\
\hline \multicolumn{7}{|l|}{ Middle } \\
\hline Have a card & 14 & 36 & 41 & 62 & 71 & 72 \\
\hline Carrying a balance & 47 & 45 & 58 & 56 & 58 & 58 \\
\hline Mean balance (dollars) & 820 & 883 & 1,161 & 2,159 & 2,952 & 4,129 \\
\hline Median balance (dollars) & 630 & 672 & 736 & 1,262 & 1,605 & 1,900 \\
\hline Share of total revolving balance & 22 & 19 & 19 & 21 & 21 & 23 \\
\hline \multicolumn{7}{|l|}{ Second highest } \\
\hline Have a card ... & 22 & 51 & 57 & 76 & 83 & 86 \\
\hline Carrying a balance & 39 & 52 & 56 & 62 & 60 & 60 \\
\hline Mean balance (dollars) & 1,010 & 846 & 1,259 & 2,212 & 2,687 & 4,334 \\
\hline Median balance (dollars) & 840 & 753 & 818 & 1,183 & 1,605 & 2,000 \\
\hline Share of total revolving balance & 37 & 30 & 28 & 30 & 23 & 29 \\
\hline \multicolumn{7}{|l|}{ Highest } \\
\hline Have a card & 33 & 69 & 79 & 89 & 95 & 95 \\
\hline Carrying a balance & 30 & 39 & 47 & 46 & 50 & 45 \\
\hline Mean balance (dollars) & 761 & 898 & 1,531 & 3,417 & 4,460 & 5,232 \\
\hline Median balance (dollars) & 630 & 672 & 916 & 2,630 & 2,246 & 2,500 \\
\hline Share of total revolving balance & 30 & 33 & 40 & 40 & 36 & 29 \\
\hline \multicolumn{7}{|l|}{ All families } \\
\hline Have a card & 16 & 38 & 43 & 56 & 66 & 68 \\
\hline Carrying a balance & 37 & 44 & 51 & 52 & 56 & 55 \\
\hline Mean balance (dollars) & 839 & 889 & 1,282 & 2,404 & 3,160 & 4,073 \\
\hline Median balance (dollars) & 630 & 672 & 818 & 1,315 & 1,605 & 1,900 \\
\hline Share of total revolving balance & 100 & 100 & 100 & 100 & 100 & 100 \\
\hline
\end{tabular}

Note. In 1970, families were asked about using cards; in all other years, they were asked about having cards. Proportions that "have a card" are percentages of families; proportions "carrying a balance" are percentages of holders of bank-type cards with an outstanding balance after the most recent payment.

Mean and median balances are for cardholders with outstanding balances after

the most recent payment and are in 1998 dollars, adjusted using the Consumer Price Index for All Urban Consumers, all items. Shares may not sum to 100 percent because of rounding.

SOURCE. Surveys of Consumer Finances.

of consumers were thirty days delinquent on at least one bank-type card account (not shown in chart). This source also shows that more serious delinquency (overdue ninety days or more) has remained at or slightly below 1 percent of holders of active banktype card accounts over the past decade. ${ }^{4}$

\section{CONSUMER INFORMATION AND CONSUMER UNDERSTANDING}

Beginning with the Truth in Lending Act (enacted in 1968 as Title I of the Consumer Credit Protection Act, effective July 1, 1969), much federal legislation regulating consumer credit has concerned either mandatory fairness procedures (the Equal Credit Opportu-

4. See Credit Research Center (McDonough School of Business, Georgetown University, Washington, D.C.), Monthly Statements, various issues.

nity Act, for example) or mandatory disclosures (the Truth in Lending Act, for example). The disclosure requirements have in large part been intended to help prevent or mitigate overextension and other difficulties resulting from a lack of understanding of credit terms and the consequences of using credit. Generalpurpose household surveys can help in assessing the effects of these laws. Unfortunately, the specifics of many individual consumer's credit-related difficulties do not lend themselves to such broad-based surveys. Surveying currently delinquent debtors, for example, is difficult with a broad survey because delinquency is relatively rare; large numbers of interviews must be completed to yield enough cases to analyze an uncommon phenomenon with precision. General-purpose surveys can, however, characterize consumers' overall impressions of their cardusing experiences and their views on conditions in the marketplace, including the availability of information. 


\section{Consumer credit delinquency rates, 1991-99}

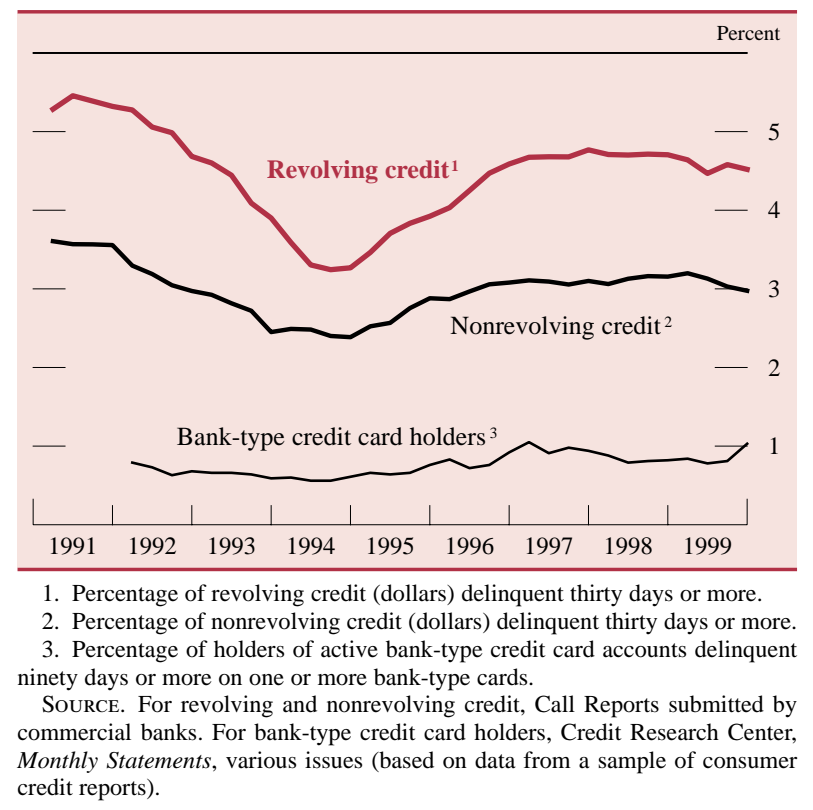

\section{Consumers' Attitudes toward Credit Cards}

To explore consumers' attitudes toward and understanding of credit cards, as well as to gather information about card use, the Credit Research Center in January 2000 sponsored interviews of nearly 500 households representative of households in the fortyeight contiguous states. Interviewing was done by the Survey Research Center of the University of Michigan as part of its monthly Surveys of Consumers.

\section{General Attitudes}

Respondents - both those who used credit cards and those who did not-were first asked their broad feelings about credit cards. So that attitude changes could be tracked over time, the question was identical to the question asked in nationwide Surveys of Consumer Finances in 1970 and again in 1977: "People have different opinions about credit cards. Overall, would you say that using credit cards is a good thing or a bad thing?"

Overall opinions about credit cards are somewhat more negative and polarized in 2000 than they were a generation ago, especially among holders of banktype cards (table 3). Opinions among all families that credit card use is "good" register a bit higher in 2000 (33 percent) than in 1970 ( 28 percent) but a bit lower than in 1977 (39 percent). The view that card use is "bad" is stronger in 2000 than in either of the earlier years.

In all three surveys, views among holders of banktype cards were more favorable than those among the population generally. Nonetheless, unfavorable views among cardholders have increased over the decades; negative attitudes among cardholders are much more common in 2000 (42 percent) than they were in 1977 (14 percent). This finding is interesting because card use is also much greater in 2000. In 2000, holders of bank-type cards are about equally divided in their opinions that credit card use is good or bad, much different from 1977, when a considerably larger proportion had a favorable opinion. ${ }^{5}$

Consumers' opinions about credit cards also vary depending on their use of and experience with cards. Less enthusiastic viewpoints are somewhat more common among those who use credit cards as credit devices rather than primarily as substitutes for cash

5. Interestingly, contrary opinions about consumer credit, even from the same person, apparently have been around much longer than these surveys. Referring to the paradox of dichotomous views as the "Victorian money-management ethic," a cultural historian recently pointed out that the simultaneous belief that credit is good but debt is bad is actually at least as old as American history. See Lendol Calder, Financing the American Dream: A Cultural History of Consumer Credit (Princeton, N.J.: Princeton University Press, 1999).

3. Opinions about the use of credit cards, selected years Percent

\begin{tabular}{|c|c|c|c|c|c|c|}
\hline \multirow{2}{*}{ Opinion } & \multicolumn{2}{|c|}{1970} & \multicolumn{2}{|c|}{1977} & \multicolumn{2}{|c|}{2000} \\
\hline & All families & $\begin{array}{l}\text { Bank-type } \\
\text { card users }\end{array}$ & All families & $\begin{array}{c}\text { Bank-type } \\
\text { card holders }\end{array}$ & All families & $\begin{array}{c}\text { Bank-type } \\
\text { card holders }\end{array}$ \\
\hline Good & 28 & 45 & 39 & 54 & 33 & 42 \\
\hline Good, with qualification & 13 & 17 & 19 & 20 & 10 & 9 \\
\hline Both good and bad & 12 & 14 & 11 & 8 & 6 & 5 \\
\hline Bad, with qualification .. & 4 & 4 & 4 & 3 & 1 & 1 \\
\hline Bad & 43 & 20 & 27 & 14 & 51 & 42 \\
\hline Total & 100 & 100 & 100 & 100 & 100 & 100 \\
\hline
\end{tabular}


or checks. Specifically, cards are viewed less positively by those who have three or more cards, have an outstanding balance of more than $\$ 1,500$, have transferred a balance between cards, hardly ever pay their outstanding balance in full, hardly ever pay more than the monthly minimum, or have received a collection call.

Prevalence of negative attitudes toward using credit cards among holders of bank-type credit cards, 2000

\begin{tabular}{|c|c|}
\hline Cardholder group & $\begin{array}{l}\text { Percent believing } \\
\text { that using credit } \\
\text { cards is bad }\end{array}$ \\
\hline All holders of bank-type cards & 42 \\
\hline Have a new card account in the past year & 47 \\
\hline Have three or more cards $\ldots \ldots \ldots \ldots \ldots$ & 49 \\
\hline $\begin{array}{l}\text { Have an outstanding balance greater than } \$ 1,500 \\
\text { after the most recent payment } \ldots \ldots \ldots \ldots \ldots\end{array}$ & 57 \\
\hline $\begin{array}{l}\text { Have transferred a balance to another account } \\
\text { in the past year }{ }^{1} \ldots \ldots \ldots \ldots \ldots \ldots \ldots \ldots\end{array}$ & 60 \\
\hline Hardly ever pay outstanding balance in full & 59 \\
\hline Hardly ever pay more than the minimum ${ }^{1}$. & 63 \\
\hline Have paid a late fee in the past year...$\ldots$ & 47 \\
\hline Have received a collection call in the past year ${ }^{1}$ & 62 \\
\hline Family's annual income is $\$ 40,000$ to $\$ 74,999$ & 49 \\
\hline $\begin{array}{l}\text { Respondent has high school diploma or some college, } \\
\text { but not a degree } \ldots \ldots \ldots \ldots \ldots \ldots \ldots \ldots \ldots\end{array}$ & 46 \\
\hline Respondent is $35^{\circ}$ to 54 years old .. & 48 \\
\hline
\end{tabular}

Conversely, those who have fewer cards, have no balance or a low balance outstanding, generally pay more than the minimum, or have not received a collection call have more favorable views (not shown in the table). Demographic measures also appear to be related to attitudes toward credit cards, but the relationship is not as strong as that associated with the variables related to the use of cards.

\section{Attitudes toward Card Features, Card Issuers, and Other Users}

To examine why card users might have the general attitudes about credit cards that they do, the 2000 survey also asked questions about specific features of credit cards and about card issuers and users. The questions took the form of statements with which respondents could agree or disagree. Although data from earlier years are not available for comparison, responses to these questions reveal an interesting divergence of views that might help explain why overall attitudes have deteriorated. The responses suggest that the current negativity may have arisen in part from an individual's perceptions of other consumers' difficulties rather than from the individual's own experiences. Without data from earlier periods and questions designed specifically to address this hypothesis, one cannot be certain, but from the 2000 survey results it seems likely that as card use has become more common, negative opinions about card use may have increased as a result of perceptions about "the other guy." Views about personal experiences with credit cards, in contrast, are much more positive.

Consumers in 2000 seem to be concerned about specific practices of credit card issuers. Most holders of bank-type credit cards (more than 80 percent) believe that the annual percentage rates charged on outstanding balances are too high (table 4). They also express concern over privacy practices. In contrast, relatively few express concern about billing accuracy.

Consumers' feelings about experiences with credit cards in general are even more negative than their feelings about specific practices. ${ }^{6}$ Holders of banktype credit cards in 2000 believe that too much credit is available, that consumers are confused about some practices, and that credit users have difficulty getting out of debt. Somewhat over half said that issuers should not be allowed to market cards to college students. Moreover, they appear to believe that consumers bring on themselves many of the problems associated with credit cards: Ninety percent agree to some extent that overspending is the fault of consumers, not of card issuers.

Survey evidence does not suggest that increasingly negative views of credit cards have arisen from adverse personal experiences. Rather, consumers' opinions about their own relations with their current card issuers are much more favorable than their opinions about the relations of consumers in general. Approximately nine in ten holders of bank-type credit cards said that they are satisfied with their dealings with card companies, that their card companies treat them fairly, and that it is easy to get another card if they are not treated fairly. Almost seven in ten trust that their own card companies would keep their personal information confidential, substantially more than the proportion believing that card companies in general show enough concern about protecting privacy (just under five in ten). Cardholders' opinions about their own experiences are almost the reverse of their views about consumers' experiences in general, suggesting considerable concern over the behavior of others and possibly a belief that "I can handle credit cards, but other people cannot."

Despite expressed concerns about some practices and experiences, consumers appear to be satisfied

6. Survey interviewers did not offer the statements in the order given in table 4; the table groups topically similar questions for analytical purposes. 
4. Attitudes of holders of bank-type credit cards toward credit cards and card issuers, 2000 Percent

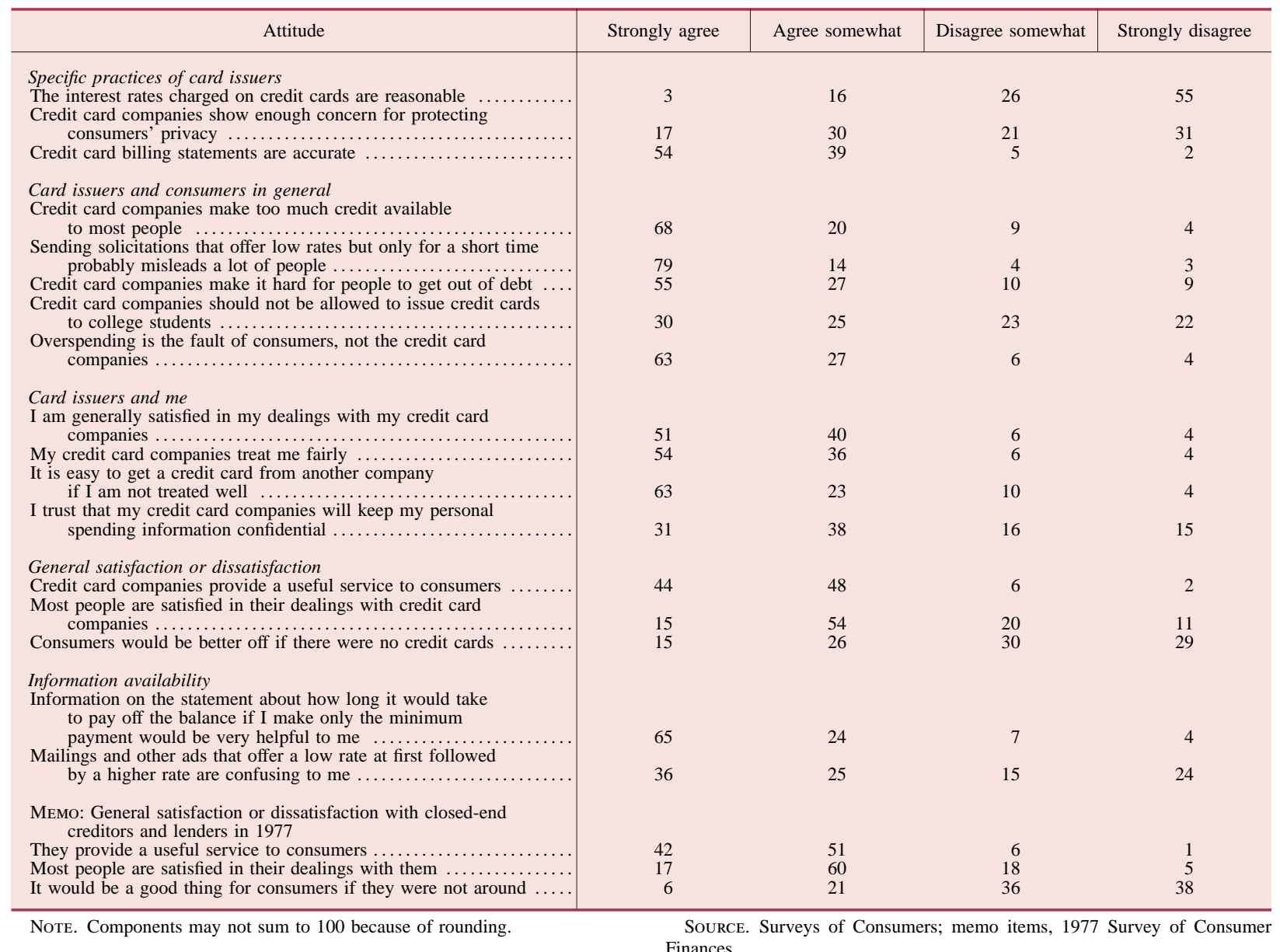

with the credit card market in general. Approximately nine in ten holders of bank-type credit cards said that credit cards provide a useful service to consumers, and about seven in ten said that most people are satisfied in their dealings with card companies. About six in ten disagreed that consumers would be better off without cards. These results are similar to those from a 1977 survey of users of nonrevolving credit (memo items in table 4). It seems that credit and creditors are not viewed completely favorably, even by users of the service, but that most users are favorably inclined.

Many holders of bank-type cards in 2000 said that it would be helpful to include on their billing statement information about the length of time it would take to pay off the balance if only the minimum payment were made each month. Exactness in such a calculation assumes, of course, that the consumer does not use the card during the repayment period and that the balance declines on schedule. If the balance were to fluctuate substantially, the calcula- tion would be difficult or impossible, and most likely meaningless (discussed further later). Survey respondents probably did not consider the implications and complexity of the calculations but were simply acknowledging a desire for a practical measure of the burden they are incurring. Many respondents also reported that "teaser rates" are confusing. They could, of course, avoid teaser rates altogether by ignoring the mailings that promote them; consequently, this survey finding may reflect concerns among consumers that card issuers have complicated promotions sufficiently that it is difficult to understand and accept advantageous offers when they are made.

What emerges from these responses to opinion questioning, in sum, is a multifaceted set of attitudes about credit cards. Multifaceted opinions are not especially surprising, given that consumers overall seem to think that credit cards are both good and bad. They believe that finance percentage rates on outstanding balances are too high, are suspicious of how 
personal information is used, and have relatively little confidence in other individuals who use credit cards. When they imagine "the other guy" in contact with card issuers, whose behavior is already suspect, they imagine possibly negative consequences, for example, excessive credit use. When the focus shifts to more-personal experience, however, they view the outcome much more favorably, suggesting that actual problems with credit cards are not nearly as widespread as consumers imagine them to be when they think about the population of largely unknown "others." On balance, holders of bank-type credit cards in 2000 believe that credit cards are useful and that consumers are better off with them than without them-despite concerns over the inability of "other (unknown) consumers" to exercise self-discipline and avoid overuse; these opinions seem to mirror earlier views about installment credit. Finally, consumers believe that additional, and less-confusing, information about payments and rates would be useful.

\section{Information about Credit Terms}

In addition to attitudes, the January 2000 Survey of Consumers specifically looked at consumers' knowledge of credit terms and their views concerning the availability of information about terms.

Assessing consumers' knowledge of credit terms and their use of that knowledge is not a straightforward matter. One question is which term or terms to focus on. A second question is how, in an interview survey, to determine the accuracy of the consumer's knowledge. Since implementation of the Truth in Lending Act, the annual percentage rate (APR) has been considered the most important term concerning the price of credit to be disclosed by creditors, and consequently it has been the credit term studied most extensively. It is reasonable to assume that credit users must be aware of annual percentage rates if disclosure of this pricing information is to affect their behavior. An awareness of APRs does not necessarily mean that consumers will change their behavior, but behavioral change resulting from disclosure of APRs is highly unlikely if credit users are not aware of those rates. ${ }^{7}$

Because in interview surveys the annual percentage rates reported by respondents typically cannot be

7. For discussion of this topic, see George S. Day, "Assessing the Effects of Information Disclosure Requirements," Journal of Marketing, vol. 40 (April 1976), pp. 42-52. checked against the rates respondents actually pay, researchers associated with the National Commission on Consumer Finance in the 1970s devised the concept of "awareness zones" to measure knowledge of APRs. ${ }^{8}$ If a respondent reports an APR within a range deemed, on the basis of a survey of current market practices, to be reasonable, the respondent is characterized as "aware"; if the respondent reports an APR outside the range or answers "do not know," the individual is characterized as "unaware." Although this is an inexact means of measuring awareness of APRs on actual credit card accounts, it does make possible a broad look at the phenomenon as well as comparisons over time.

"Awareness" of APRs on bank-type credit cards, as measured by the awareness-zones method, has increased sharply since implementation of the Truth in Lending Act in 1969 (table 5). In that year, only 27 percent of holders of bank-type credit cards interviewed in a Federal Reserve survey were classified as aware. Awareness more than doubled a year after implementation of the act and has continued to rise since then.

In 1969, 1970, and 1977, consumers were considered aware if they reported a rate greater than 12 percent per year or within the range of 1 percent to 2 percent per month on the card they used most often. For the 2000 survey, the definition of "aware" was changed because rates on credit card balances in many cases are below 12 percent per year-and so-called teaser rates are even lower. Because a very low rate could not be automatically ruled out as the correct current rate, two definitions of awareness were used in 2000. Under the broad definition, only those reporting that they did not know the rate were considered "unaware." Under the narrow definition, those reporting a rate of less than 7.9 percent were also considered unaware. (Using 7.9 percent as the cutoff point may have resulted in an overestimation of unawareness, as some consumers may have actually had a current, "teaser," rate below 7.9 percent: Almost every answer lower than 7.9 percent offered by a respondent ended in .9-for example, 3.9 or

8. See National Commission on Consumer Finance, Consumer Credit in the United States: The Report of the National Commission on Consumer Finance (Government Printing Office, 1972); Robert P. Shay and Milton P. Schober, Consumer Awareness of Annual Percentage Rates of Charge in Consumer Installment Credit: Before and After Truth in Lending Became Effective, Technical Studies of the National Commission on Consumer Finance, vol. 1, no. 1 (Government Printing Office, 1973); George S. Day and William K. Brandt, A Study of Consumer Credit Decisions: Implications for Present and Prospective Legislation, Technical Studies of the National Commission on Consumer Finance, vol. 1, no. 2 (Government Printing Office, 1973). 
5. Awareness of annual percentage rates among holders of bank-type credit cards, selected years

Percent aware

\begin{tabular}{|c|c|c|c|c|c|}
\hline \multirow{2}{*}{ Cardholder group } & \multirow{2}{*}{1969} & \multirow{2}{*}{1970} & \multirow{2}{*}{1977} & \multicolumn{2}{|c|}{2000} \\
\hline & & & & Narrow definition & Broad definition \\
\hline All holders of bank-type cards & 27 & 63 & 71 & 85 & 91 \\
\hline Have a new card account in the past year & $\ldots$ & $\ldots$ & $\ldots$ & 83 & 93 \\
\hline Have three or more cards $\ldots \ldots \ldots \ldots \ldots \ldots \ldots$ & $\cdots$ & .. & & 89 & 95 \\
\hline $\begin{array}{l}\text { Have an outstanding balance greater than } \$ 1,500 \\
\text { after the most recent payment }\end{array}$ & & $\ldots$ & & 90 & 06 \\
\hline Have transferred a balance to another account & & & & & \\
\hline in the past year ${ }^{1} \ldots \ldots \ldots \ldots \ldots \ldots \ldots$ & $\cdots$ & . . & ... & 81 & 98 \\
\hline Hardly ever pay outstanding balance in full & $\ldots$ & $\ldots$ & $\ldots$ & 90 & 96 \\
\hline Hardly ever pay more than the minimum 1 & $\ldots$ & . & . & 82 & 88 \\
\hline Have paid a late fee in the past year & $\ldots$ & . & . & 88 & 95 \\
\hline Have received a collection call in the past year ${ }^{1}$ & $\ldots$ & $\therefore$ & $\because$ & 80 & 81 \\
\hline $\begin{array}{l}\text { Family's annual income is } \$ 40,000 \text { to } \$ 74,999 \\
\text { Respondent has high school diploma or some }\end{array}$ & $\ldots$ & $\cdots$ & $\ldots$ & 90 & 94 \\
\hline college, but not a degree $\ldots . . . \ldots$. & $\ldots$ & . & . & 86 & 91 \\
\hline Respondent is 35 to 54 years old $\ldots \ldots \ldots$. & $\ldots$ & 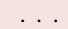 & & 87 & 92 \\
\hline
\end{tabular}

NotE. See text for definitions of "awareness."

1. Weighted sample size less than fifty.

.. . Not available.

Source. For 1969 and 1970, Federal Reserve Truth in Lending Surveys; for 1977, Survey of Consumer Finances; for 2000, Surveys of Consumers.

6.9-a sign of a teaser rate. However, this inexactitude on the lower side does not change conclusions very much.) The definition of the upper bound for the 2000 survey is of little practical importance, as only one respondent answered with a rate higher than 25 percent (with a response of 28 percent, this individual was counted as aware).

Under the broad definition of awareness, 91 percent of holders of bank-type credit cards in 2000 are aware of the APR charged on the outstanding balance on the bank-type card they use most often; under the narrow definition 85 percent are aware. Regardless of the definition used in 2000, it is clear that awareness of rates charged on outstanding balances, as measured by the awareness-zones method, has risen sharply since implementation of the Truth in Lending Act.

As with attitudes, awareness of rates varies by behavioral and demographic group. However, awareness exceeds 80 percent for all groups by both the broad and narrow definitions. Groups tending to be less aware (based on the broad definition) include the relatively small group of cardholders who had received a collection call in the past year (81 percent were aware) and those who hardly ever pay more than the minimum amount on their account (88 percent). The group of cardholders who had transferred a balance to another account within the past year registered the highest awareness rate (98 percent), consistent with the belief that balance transfers are more likely among rate-sensitive consumers (and also with the belief that rates on newly transferred accounts are easy to remember)..$^{9}$ Other groups having relatively high awareness rates include those actually paying the rates, notably, consumers with an outstanding balance of more than $\$ 1,500$ and those who reported that they hardly ever pay their outstanding balance in full (for both groups, 96 percent). High awareness among these groups is not especially surprising, as consumers who use the credit feature of credit cards, as opposed to just the payment feature, have a clear interest in knowing the cost of the additional service.

Potentially as important as actual awareness is the perception of ease of obtaining information about credit terms. About two-thirds of consumers in the 2000 survey who had bank-type credit cards said that obtaining information on credit terms is easy (table 6). The proportion did not vary greatly or consistently with the way the respondents used credit. Those who had an outstanding balance of more than $\$ 1,500$ or had transferred a balance from one card to another in the past year were somewhat less likely to report ease in obtaining information, as were those who had received a collection call. Conversely, those who had three or more cards, hardly ever paid more than the minimum amount, or had income in the middle range were slightly more likely to report ease in obtaining information.

9. The large difference between the rates for the narrow and broad measures for this group and also for those with new accounts suggests that some respondents may have been reporting teaser rates and should be counted as aware under the narrow definition, as they were under the broad definition. 
6. Opinions about the availability of information about credit cards among holders of bank-type credit cards, 2000 Percent aware

\begin{tabular}{|c|c|c|c|}
\hline \multirow{2}{*}{ Cardholder group } & \multicolumn{2}{|c|}{ Information about credit terms } & \multirow{2}{*}{$\begin{array}{c}\text { Information needed } \\
\text { for wise card use }\end{array}$} \\
\hline & $\begin{array}{l}\text { Very/somewhat easy } \\
\text { to obtain }\end{array}$ & $\begin{array}{l}\text { Very difficult } \\
\text { to obtain }\end{array}$ & \\
\hline MEмO: All families & 67 & 8 & 40 \\
\hline All holders of bank-type cards & 65 & 7 & 46 \\
\hline Have a new card account in the past year & 63 & 8 & 47 \\
\hline Have three or more cards ...................... & 69 & 4 & 44 \\
\hline Have an outstanding balance greater than $\$ 1,500$ & 6 & r & 2 \\
\hline $\begin{array}{l}\text { atter the most recent payment } \\
\text { Have transferred a balance to another account in the past year }{ }^{1}\end{array}$ & $\begin{array}{l}60 \\
58\end{array}$ & $\begin{array}{r}5 \\
14\end{array}$ & $\begin{array}{l}36 \\
42\end{array}$ \\
\hline Hardly ever pay outstanding balance in full & 65 & 7 & 46 \\
\hline Hardly ever pay more than the minimum ${ }^{1}$. & 69 & 11 & 36 \\
\hline Have paid a late fee in the past year .... & 62 & 12 & 36 \\
\hline Have received a collection call in the past year ${ }^{1}$ & 57 & 12 & 28 \\
\hline Family's annual income is $\$ 40,000$ to $\$ 74,999$. & 68 & 4 & 45 \\
\hline Respondent has high school diploma or some college, but not a degree & 67 & 3 & 46 \\
\hline Respondent is 35 to 54 years old .............. & 63 & 8 & 48 \\
\hline
\end{tabular}

1. Weighted sample size less than fifty.

SouRCE. Surveys of Consumers.

Only 8 percent of all families and 7 percent of holders of bank-type cards believe that obtaining information on credit terms is very difficult. These proportions also vary according to consumer experience and behavior. The proportion is highest for those who have transferred a balance in the past year, those who hardly ever pay more than the minimum due on their accounts, those who have paid a late fee in the past year, and those who have received a collection call in the past year. However, in no case does the proportion rise as high as 15 percent of cardholders.

The proportions of holders of bank-type cards reporting that obtaining information on terms is easy or difficult in 2000 is similar to the proportions in earlier surveys, although in the earlier years the focus was on credit generally rather than credit cards. The proportion of all families indicating in earlier years that obtaining information on credit terms was very easy or somewhat easy ranged from 57 percent to 68 percent, and the proportion indicating that obtaining information was very difficult never rose as high as 10 percent (table 7). The proportion saying that obtaining information was easy was, in all but one year, higher among credit users than among all families, and the proportion saying that obtaining information was very difficult was lower in every year.

The 2000 survey also asked whether credit card companies "usually give enough information to people to enable them to use their credit cards wisely." A bit under half (46 percent) of holders of bank-type cards answered "yes" (table 6). This frequency seemed low in light of the widespread use of credit cards, raising the question of whether the "other guy" effect discussed earlier might be exerting a negative bias. Some consumers might believe that they personally have enough information but that other consumers, who can be counted on to make mistakes when dealing with card issuers, do not. A question focused on the respondents' own experiences might have produced a higher positive response.

To explore these possibilities, two indexes of overall attitudes-one of negativity toward the "other guy" and the other of positiveness about personal experiences-were constructed from responses to

7. Opinions about the ease of obtaining information about credit terms, selected years, 1977-2000

Percent

\begin{tabular}{|c|c|c|}
\hline Group/year & $\begin{array}{l}\text { Very/somewhat } \\
\text { easy }\end{array}$ & Very difficul \\
\hline All families & & \\
\hline $1977 \ldots$. & 58 & 9 \\
\hline 1981 & 68 & 7 \\
\hline 1984 & 57 & 8 \\
\hline 1993-4 & 63 & 7 \\
\hline $1997 \ldots$ & 59 & 9 \\
\hline 2000 & 67 & 8 \\
\hline Credit users ${ }^{1}$ & & \\
\hline $1977 \ldots \ldots$ & 63 & 8 \\
\hline 1981 & 78 & 3 \\
\hline 1984 & 62 & 1 \\
\hline 1993-4 & 72 & 5 \\
\hline 1997 & 72 & 3 \\
\hline 2000 & 65 & 7 \\
\hline
\end{tabular}

NoTE. For 2000, ease of obtaining information about credit card terms; for all other years, information about credit terms.

1. For 1977, families with (closed-end) installment debt outstanding; for 1981, 1993-94, and 1997, families that had incurred (closed-end) installment debt in the past year; for 1984, families that had made a purchase on the installment plan in the past year; for 2000, holders of bank-type credit cards.

SouRCE. For 1977, Survey of Consumer Finances; for all other years, Surveys of Consumers. 
statements about "card issuers and consumers in general" and "card issuers and me" (see table 4). For each of the five statements in the former category, which are framed to reflect negatively on issuers and consumers, a value of -2 was assigned to each "strongly agree" response and a value of -1 was assigned to each "agree" response; other responses were assigned a value of zero. The values were then summed for each respondent, giving an index value within a range of -10 to zero for that respondent. The respondents were then divided into two groups, "strongly negative" (an index value of -7 through -10 , characterizing about 42 percent of holders of bank-type cards) and all others. A similar but positive index was constructed from the favorable responses to the statements about personal experiences ("card issuers and me" in table 4); and the respondents were similarly divided into two groups, "strongly positive" (about 49 percent of holders of bank-type cards) and all others.

Respondents who were not strongly negative about other consumers were in fact somewhat more likely to believe that card issuers give cardholders enough information to enable them to use their credit cards wisely; 52 percent of this group answered this way, compared with 46 percent of all cardholders. Of the group with a strongly positive index for personal experiences, 55 percent said issuers provide enough information (figures not in the tables). Although the differences are not dramatic, it does seem likely that the "other guy" effect exerts a downward bias on views as to whether credit card issuers provide enough information. Even with the possible downward bias, about two-fifths of all families in 2000 believe that creditors provide enough information. ${ }^{10}$

Holders of bank-type credit cards who said either that card issuers do not provide enough information or that they do not know were also asked a follow-up question: "What kind of information do you think would be helpful?" The wording of the question permits thinking about other consumers as well as more personally. The responses suggest a concern about the clarity of already available information (table 8), raising a question as to whether the required information provided now is so extensive and fre-

10. It is also possible to examine the association of strongly negative and positive attitudes with overall beliefs that credit cards are good or bad (the measurement in table 3 ). Notably, 55 percent of those in the strongly negative group (that is, those who expressed negativity on the questions about consumers) believe that credit cards are "bad" (a percentage much higher than that for the population as a whole), compared with 35 percent of those in the strongly positive group (that is, those who feel positive about their personal experiences) (much lower than the percentage for the population as a whole).
8. Proportion of holders of bank-type credit cards believing that specific actions to provide more information would be helpful, 2000

Percent

\begin{tabular}{c|c|c}
\hline Action & $\begin{array}{c}\text { Bank-type card } \\
\text { holders who said } \\
\text { more information } \\
\text { would be helpful }\end{array}$ & $\begin{array}{c}\text { All bank-type } \\
\text { card holders }\end{array}$ \\
\hline $\begin{array}{c}\text { Clearly state interest rates and } \\
\text { changes in interest rates ..... }\end{array}$ & 35 & 19 \\
$\begin{array}{c}\text { Clearly define fees and charges .... } \\
\text { Make fine print bigger ........... }\end{array}$ & 15 & 8 \\
$\begin{array}{c}\text { Offer credit counseling ........... } \\
\text { Provide more information } \\
\text { about overextension .......... }\end{array}$ & 12 & 6 \\
$\begin{array}{c}\text { Give information about costs } \\
\text { if only the minimum amount } \\
\text { is paid ..................... }\end{array}$ & 11 & 6 \\
All other responses ............... & 14 & 6 \\
\hline
\end{tabular}

Note. Respondents were allowed to answer with up to two responses. Source. Surveys of Consumers.

quent that it is almost overwhelming. Those who said that more information would be helpful simultaneously seem to be saying that they do not understand the information already provided, as many of the features they said would be helpful-clear statement of interest rates and changes in rates, and a clear definition of fees for cash advances and other services, for example-are already required by disclosure regulations. Respondents indicating that credit counseling and information about overextension would be useful could be expressing concern for others as well as for themselves.

\section{Information about Payoff Times}

Some observers have proposed that the Truth in Lending Act be amended to require card issuers to disclose to cardholders the period of time necessary to pay off a credit card balance if only the minimum amount is paid each month. Consumers indicate that they would like to have this information. However, precision in such a figure would imply that the consumer would not add to the balance in subsequent months (an assumption that also might be disclosed). If the consumer makes the minimum payment but continues to use the card, and the balance fluctuates substantially, the disclosure would in many cases be inaccurate. Of course, some consumers who rarely pay the balance in full might, nonetheless, benefit from an imperfect glimpse of the length of time necessary to repay in full.

To learn about consumers' behavior with respect to paying balances and the likelihood of their ceasing to 
use the card after paying only the minimum amount, questions on this subject sponsored by the Federal Reserve were asked in the monthly Surveys of Consumers undertaken by the Survey Research Center of the University of Michigan in the summer of 1999, and identical questions sponsored by the Credit Research Center were included in the Surveys of Consumers in January 2000. In all, 2,000 consumers were questioned. Findings that 73 percent had a credit card of some type and 69 percent had a banktype card correspond well with results of the 1998 Survey of Consumer Finances.

Just over one-third (35 percent) of holders of banktype cards said they hardly ever pay their balance in full, somewhat higher than the 27 percent found in the 1998 Survey of Consumer Finances. Nine percent of cardholders reported that they sometimes pay more than the minimum amount due, and only 7 percent said they hardly ever pay more than the minimum.

Card-related behaviors among holders of bank-type credit cards, 1999 and 2000

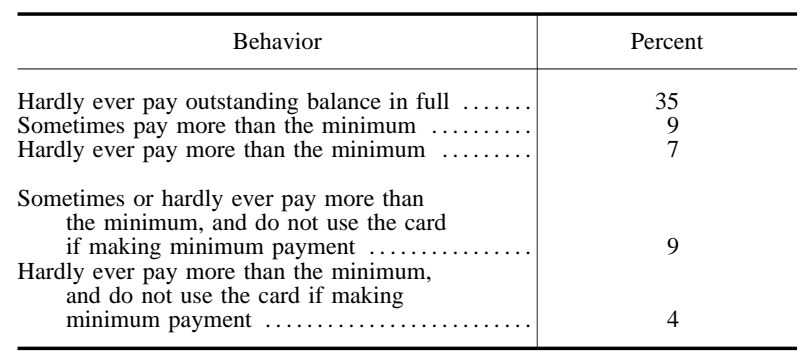

SourCE. Surveys of Consumers, June-August 1999 and January 2000.

As discussed earlier, those who would benefit most directly from information about the length of time it would take to pay off a revolving account by making only the minimum payment each month would be card users who pay the minimum and then do not make additional charges (as noted, if they continued to use the accounts, the length of time to repay would change). Survey findings indicate that 9 percent of holders of bank-type cards are in this category. If only those who say they hardly ever pay more than the minimum are considered, the proportion who report that they stop using the card falls to 4 percent of holders of bank-type cards.

\section{CONCLUSION}

The holding and use of general-purpose credit cards with a revolving feature, as well as balances outstanding, have increased substantially over the past three decades. These "bank-type" credit cards are, to some extent, a substitute for the installment-purchase plans formerly offered by retail stores. Consumers apparently like the convenience associated with card-based open-end credit lines, but they also express concerns. Some of their concerns may arise from personal experiences, but some also apparently come from perceptions of the difficulties of other consumers. Many consumers, by one measure of one important credit cost term, are aware of the costs associated with the use of revolving credit, and most consumers say that obtaining information on credit card terms is not very difficult. Responses to consumer interviews suggest that attitudes toward credit cards and card companies are similar to attitudes about closed-end credit in an earlier generation. Credit and creditors are never universally popular, it seems, even among users, and technological change in credit issuance has not altered this observation. 